\title{
UJI PAKAN LIMBAH BAYAM DALAM RANSUM TERHADAP KONSUMSI PAKAN, PERTAMBAHAN BOBOT BADAN DAN KONVERSI PAKAN AYAM KAMPUNG (Gallus domesticus)
}

\author{
Sri Pangestuti ${ }^{1}$, Aminuddin Umasangadji ${ }^{2}$, Nirmala F. $\mathrm{F}^{3}$ \\ ${ }^{1,3}$ Jurusan Biologi Fakultas Matematika dan Ilmu Pengetahuan Alam \\ ${ }^{2}$ Jurusan Pertanian Unpatti Ambon \\ E-mail: $\underline{\text { sri_pagestuti12@yahoo.co.id }}$
}

\begin{abstract}
Abstrak: Ayam kampung merupakan sumber protein hewani yang sangat potensial dan mempunyai prospek untuk dikembangkan. Namun kenyataannya masih banyak ternak ayam kampung yang diusahakan produktifitasnya tidak maksimal, selain itu pakan yang diberikan juga belum memiliki standar nutrisi yang tepat. Untuk meningkatkan produktivitas ternak perlu dilakukan upaya mencari sumber pakan alternatif. Salah satu alternatif yang dapat digunakan adalah dengan memanfaatkan limbah bayam. Penelitian ini bertujuan untuk mengetahui pengaruh pemberian limbah bayam dalam ransum terhadap konsumsi pakan, pertambahan bobot badan dan konversi pakan ayam kampung periode grower. Hasil analisis statistik menunjukkan bahwa pemberian limbah bayam dalam ransum berpengaruh tidak nyata $\left(\mathrm{F}_{\text {hitung }}<\mathrm{F}_{\text {tabel }}\right)$ terhadap konsumsi pakan, pertambahan bobot badan dan konversi pakan ayam kampung periode grower
\end{abstract}

Kata Kunci: Ayam Kampung, Konsumsi Pakan, Bobot Badan, Konversi Pakan

\section{WASTE SPINACH IN TEST FEED RATIONS TO FEED CONSUMPTION, THE ADDITION OF ANOTHER BODY WEIGHT AND CONVERSION OF VILLAGE CHICKEN FEED (Gallus domesticus)}

\begin{abstract}
Chicken is a source of animal protein which is really potential and have the prospects for developed. But the fact remains much livestock chicken planted their productivities are only, the feed given has not had proper nutrition standards. To increase productivity of cattle should be the effort to recruit alternative source of feed. One of alternatives that can be used is to utilize the wastes spinach. Research aims to understand the influence of the provision of waste spinach in rations to consumption feed, extra weight agencies and conversion feed chicken the period grower. The results of the analysis statistics show that the waste spinach in rations influential not real of consumption feed, extra weight agencies and conversion feed chicken the period grower
\end{abstract}

Keywords: Chicken, Feed Consumption, Body Weight, The Conversion Of Feed

BIOLOGI SEL (VOL 6 NO 1 EDISI JAN-JUN 2017 ISSN 2252-858X/E-ISSN 2541-1225) PAGE 1 
Sektor peternakan dapat terus meningkatkan peranan sebagai penghasil pangan protein hewani yang bernilai gizi tinggi, di samping sebagai upaya membuka lapangan pekerjaan, peningkatan pendapatan petani/peternak. Semakin meningkatnya permintaan produk peternakan untuk memenuhi kebutuhan pangan maupun industri yang diiringi dengan semakin terbatasnya sumber daya peternakan menuntut kita untuk mengelola sumber daya tersebut secara efektif dan optimal. Oleh karena itu pemberdayaan masyarakat agrobisnis khususnya peternak, mampu memanfaatkan potensi ekonomi yang ada dipedesaan dan mampu meningkatkan produktivitas peternakan serta produk-produk olahan peternakan yang dilakukan dengan pengembangan sistem agrobisnis yang efisien dan menguntungkan serta berwawasan lingkungan (Bakri Suneth, 2003).

Ayam buras alias ayam bukan ras merupakan jenis ayam yang banyak dipelihara orang Indonesia, terutama di daerah pedesaan. Banyak nama yang dipakai untuk menyebut ayam itu. Di antarnya ada yang menyebutnya ayam lokal, ayam sayur, atau ayam kampung. Ayam buras yang terdapat di Indonesia sangat beragam penampilannya dan penyebarannya cukup luas di kota maupun di desa. Hal itu menunjukkan bahwa ayam buras punya potensi sangat baik untuk dikembangkan, terutama dimanfaatkan untuk meningkatkan gizi masyarakat dan menaikkan pendapatan keluarga (rawono. B, 210). Pakan merupakan biaya tertinggi dalam usaha peternakan, termasuk usaha ternak ayam buras yang dikelola secara intensif. Ketersediaan pakan yang terbatas dibandingkan dengan populasi manusia dan ternak, menyebabkan Indonesia harus mengimpor bahan pakan dari negara lain.

Makanan ayam banyak macam ragamnya, tiap-tiap perusahaan peternak ayam membuat makanan ayam menurut resepnya masing-masing. Jadi tiap-tiap perusahaan mempunyai susunan makanan ayam yang tentunya satu sama lain tidak akan sama penggunaan bahan-bahan dan campuran-campurannya. Namun demikian, pada prinsipnya adalah sama mengenai bahan-bahan yang dikandung dan kegunaannya. Bahan-bahan makanan untuk tiap daerah/wilayah tidaklah sama. Oleh karena itu jika kita hendak membuat campuran makanan terlebih dahulu dipilih bahan-bahan makanan yang terdapat pada daerah kita masing-masing, mudah untuk didapatkan dan murah harganya sepanjang masih memenuhi prinsip-prinsip kebutuhan ayam akan zat-zat untuk pertumbuhannya (Sukanto, 1997).

Untuk meningkatkan produktivitas ternak perlu dilakukan upaya mencari sumber pakan alternatif yaitu dengan cara mengganti sebagian bahan-bahan pakan dengan bahan pakan yang lain yang lebih murah, mudah diperoleh, dan bergizi tinggi. Salah satu alternatif yang dapat digunakan adalah dengan memanfaatkan limbah bayam (Luluk Masrurah, 2008). Limbah sayuran (bayam) memiliki nilai gizi rendah yang ditunjukkan dengan kandungan serat kasar tinggi, dengan kadar air yang tinggi pula. Limbah sayuran (bayam) berpotensi untuk dijadikan bahan pakan alternatif untuk ayam kampung. Secara fisik, limbah sayuran (bayam) mudah busuk karena berkadar air tinggi, namun secara 
kimiawi mengandung protein, serta vitamin dan mineral yang relatif tinggi dan dibutuhkan oleh ayam (Denny Rusmana, tanpa tahun).

\section{METODE PENELITIAN}

Jenis penelitian yang digunakan dalam penelitian ini adalah kuantitatif dan rancangan penelitian yang digunakan dalam penelitian ini adalah Rancangan Acak Lengkap (RAL), dengan 5 (lima) perlakuan dan setiap perlakuan terdiri dari 4 (empat) ulangan. Perlakuan yang digunakan adalah sebagai berikut:

P0 : $0 \%$ bayam

P1 : $5 \%$ bayam dari total dedak padi

$\mathrm{P} 2: 10 \%$ bayam dari total dedak padi

P3 : $15 \%$ bayam dari total dedak padi

P4 : $20 \%$ bayam dari total dedak padi

Variabel bebas yang digunakan dalam penelitian ini adalah jumlah presentasi penggunaan bayam yaitu $0 \%$ (kontrol), 5\%, 10\%, 15\% dan 20\%. Variabel terikat dalam penelitian ini merupakan variabel yang dapt diukur yaitu pertambahan bobot badan, konsumsi pakan, dan konversi pakan. Ternak percobaan yang digunakan dalam penelitian ini adalah 20 ekor ayam kampung periode grower yang berumur 9-12 minggu dan berasal dari peternakan ayam kampung milik Bapak Ir Aminudin Umasangaji, M.P.

Langkah-langkah pembuatan ransum adalah sebagai berikut: Mempersiapkan alat dan bahan pembuatan ransum, Mencuci limbah bayam dengan air bersih, Memotong limbah bayam hingga menjadi potongan kecil, Mencampur semua bahan pakan (dedak, limbah bayam dan air) dan diaduk sampai rata. Langkah-langkah pemberian pakan adalah sebagai berikut: Menimbang ransum sesuai dengan kebutuhan ayam dan Memberikan ransum setiap pagi dan sore hari. Konsumsi pakan dihitung berdasarkan penimbangan pakan pemberian dikurangi sisa pakan dalam satuan gram, Penimbangan berat badan ayam dilakukan setiap minggu selama satu bulan, dan Konversi ransum diperoleh dengan menghitung perbandingan jumlah pakan yang dikonsumsi dengan pertambahan bobot badan yang diperoleh selama penelitian

Data hasil penelitian yang meliputi konsumsi pakan dan pertambahan bobot badan dianalisis menggunakan analisis varian (sidik ragam), bila terdapat perbedaan yang nyata dilanjutkan dengan uji BNT 5\%

\section{HASIL DAN PEMBAHASAN}

\section{Konsumsi Pakan}

Rata-rata konsumsi pakan ayam kampung periode grower selama penelitian ditampilkan pada Tabel 1 berikut: 
Tabel 1. Hasil Penelitian Konsumsi Pakan Ayam Kampung (Gram)

\begin{tabular}{|l|l|l|l|l|l|l|}
\hline \multirow{2}{*}{ Perlakuan } & \multicolumn{4}{|l|}{ Minggu } & \multicolumn{4}{|l|}{ Total } & \multirow{2}{*}{ Rata-rata } \\
\cline { 2 - 7 } & 1 & 2 & 3 & 4 & & \\
\hline P0 & 590 & 623 & 596 & 533 & 2.342 & 585,5 \\
\hline P1 & 615 & 671 & 593 & 471 & 2.350 & 587,5 \\
\hline P2 & 655 & 609 & 624 & 548 & 2.436 & 609 \\
\hline P3 & 650 & 612 & 493 & 552 & 2.307 & 578,75 \\
\hline P4 & 651 & 605 & 656 & 500 & 2.412 & 603 \\
\hline Jumlah & & & & & 11.847 & $2.961,75$ \\
\hline
\end{tabular}

(Sumber: Data Penelitian, April 2016)

Berdasarkan data pada Tabel 1, tampak bahwa rata-rata konsumsi pakan ayam kampung periode grower untuk setiap perlakuan adalah $\mathrm{P}_{0}$ (tanpa pemberian limbah bayam) sebesar 585,5 gram, $\mathrm{P}_{1}(5 \%)$ sebesar 587,5 gram, $\mathrm{P}_{2}(10 \%)$ sebesar 609 gram, $\mathrm{P}_{3}$ (15\%) sebesar 578,75 gram, dan $\mathrm{P}_{4}(20 \%)$ sebesar 603 gram. Hal ini menunjukkan bahwa rata-rata konsumsi pakan ayam kampung periode grower tertinggi pada $\mathrm{P}_{2}$ (609 gram) dan terendah pada $\mathrm{P}_{3}$ (578,75 gram). Pengaruh pemberian limbah bayam terhadap konsumsi pakan ayam kampung periode grower tersebut selanjutnya ditampilkan pada diagram pada Gambar 1.

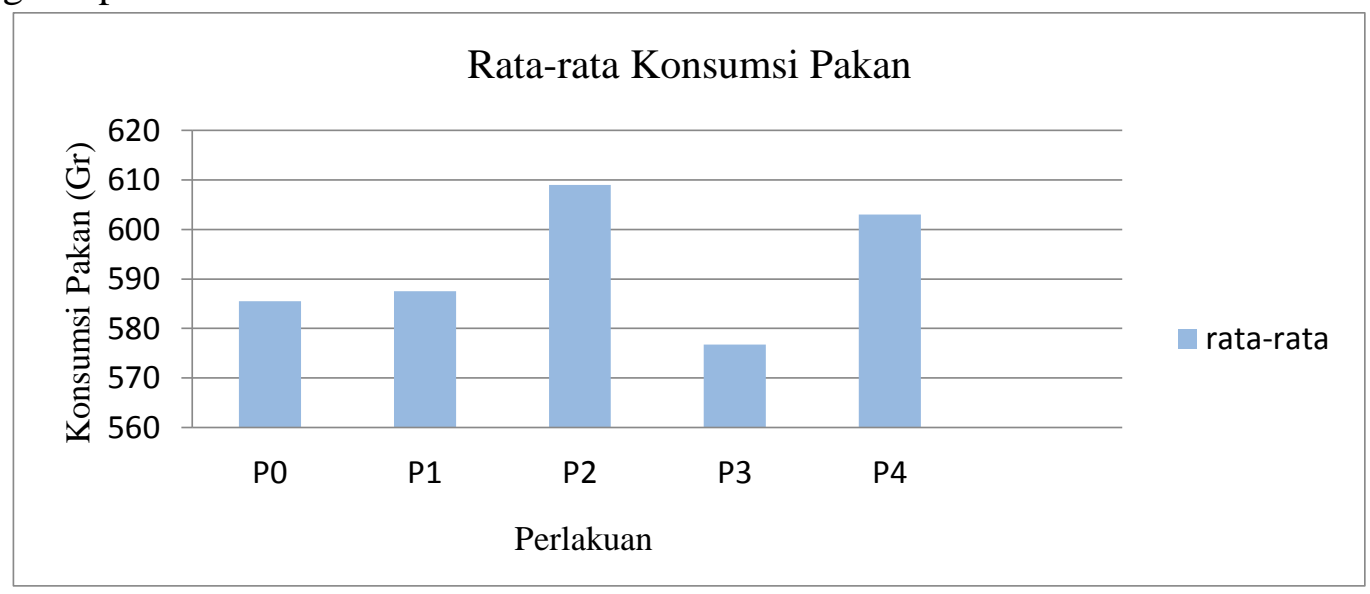

Gambar 1. Diagram Konsumsi Pakan Pakan Ayam Kampung Periode Grower

Dari hasil penelitian konsumsi pakan ayam kampung periode grower pada tabel 1, selanjutnya dilakukkan analisis ragam dengan menggunakan ANAVA (analisis varians) pola Rancangan Acak Lengkap (RAL) disajikan pada Tabel 2 berikut:

Tabel 2. Analisis Sidik Ragam Perlakuan Pemberian Limbah Bayam

\begin{tabular}{|c|c|c|c|c|c|}
\hline Sumber keragaman & $\mathrm{Db}$ & JK & KT & $F_{\text {hitung }}$ & $\mathrm{F}_{\text {tabel } 5 \%}$ \\
\hline Perlakuan & 4 & $2.817,8$ & 704,45 & \multirow{3}{*}{$0,193^{\text {tn }}$} & \multirow{3}{*}{3,06} \\
\hline Galat & 15 & $54.630,75$ & $3.642,05$ & & \\
\hline Total & 19 & $57.448,55$ & $4.346,5$ & & \\
\hline
\end{tabular}


Keterangan: ${ }^{\text {tn }}$ berpengaruh tidak nyata

Uji statistik dengan menggunakan ANAVA secara RAL untuk pemberian limbah bayam terhadap konsumsi pakan ayam kampung pada periode grower diperoleh $F_{\text {hitung }}$ $(0,193)<F_{\text {tabel }}(3,06)$ menunjukan pengaruh tidak nyata sehingga tidak dilanjutkan dengan uji Beda Nyata Terkecil (BNT).

\section{Pertambahan Bobot Badan}

Hasil penelitian rata-rata berat badan ayam kampung periode grower selama pemberian limbah bayam menunjukkan bahwa untuk masing-masing perlakuan mulai yakni $\mathrm{P}_{0}, \mathrm{P}_{1}, \mathrm{P}_{2}, \mathrm{P}_{3}$ dan $\mathrm{P}_{4}$ adalah berturut-turut sebagai berikut: 812,5; 762,5 800; 562,5; dan 925 .

Tabel 3. Hasil Penelitian Pertambahan Bobot Badan Ayam Kampung (Gram)

\begin{tabular}{|l|l|l|l|l|l|l|}
\hline \multirow{2}{*}{ Perlakuan } & \multicolumn{4}{|l|}{ Minggu } & \multirow{2}{*}{ Total } & \multirow{2}{*}{ Rata-rata } \\
\cline { 2 - 7 } & 1 & 2 & 3 & 4 & & \\
\hline P0 & 310 & 390 & 630 & 820 & 2.150 & 537,5 \\
\hline P1 & 230 & 350 & 570 & 550 & 1.700 & 425 \\
\hline P2 & 250 & 340 & 500 & 760 & 1.850 & 462,5 \\
\hline P3 & 100 & 210 & 420 & 400 & 1.130 & 282,5 \\
\hline P4 & 200 & 180 & 300 & 500 & 1.180 & 295 \\
\hline Jumlah & & & & 8.010 & 2002,5 \\
\hline
\end{tabular}

(Sumber: Data Penelitian, April 2016)

Berdasarkan Tabel 3, menunjukkan bahwa rata-rata pertambahan bobot badan ayam kampung pada periode grower untuk setiap perlakuan adalah $\mathrm{P}_{0}$ (kontrol) sebesar 537,5 gram, $\mathrm{P}_{1}(5 \%)$ sebesar 425 gram, $\mathrm{P}_{2}(10 \%)$ sebesar 462,5 gram, $\mathrm{P}_{3}(15 \%)$ sebesar 282,5 gram, dan $\mathrm{P}_{4}$ (20\%) sebesar 295 garam. Hasil tersebut menunjukkan bahwa terjadi pertambahan bobot badan ayam kampung periode grower yang berbeda pada setiap perlakuan pemberian pakan dari limbah bayam, yakni tertinggi pada $\mathrm{P}_{0}$ (tanpa penambahan limbah bayam) dan yang terendah pada perlakuan $\mathrm{P}_{3}$ (pemberian limbah bayam $15 \%$ ).

Rata-rata pengaruh pemberian limbah bayam terhadap pertambahan bobot badan ayam kampung periode grower tersebut ditampilkan pada Gambar 2 berikut: 


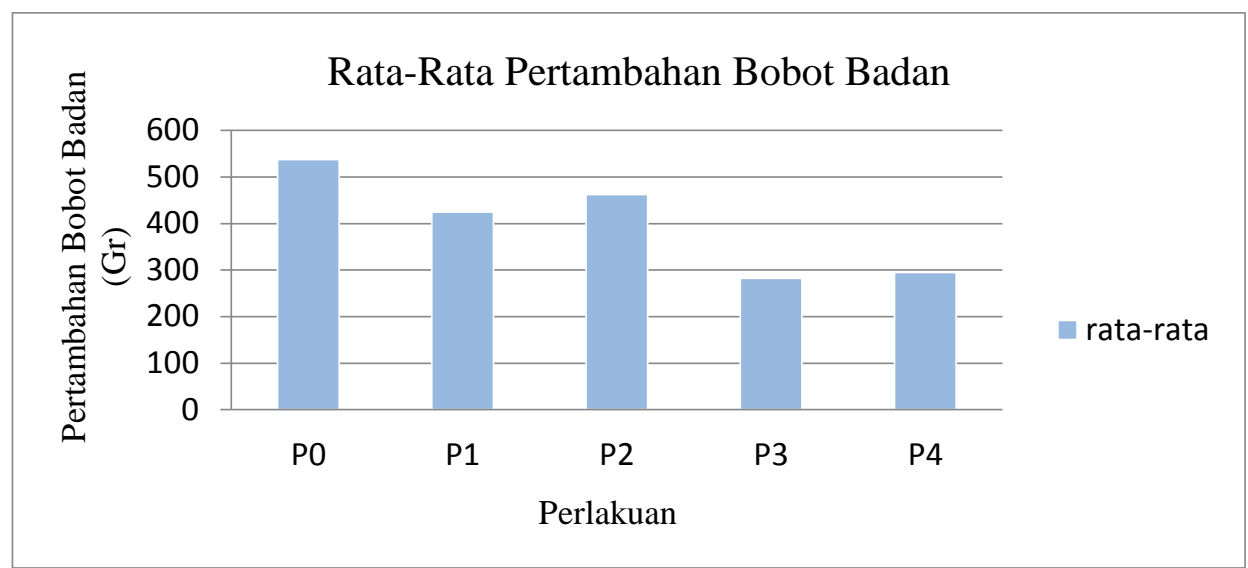

Gambar 2. Pertambahan Bobot Badan Ayam Kampung Periode Grower

Selanjutnya dilakukan analisis statistik menggunakan ANAVA (analisis varians) dengan model Rancangan Acak Lengkap (RAL) dapat dilihat pada Tabel 4.

Tabel 4. Analisis Sidik Ragam Perlakuan Pemberian Bayam

\begin{tabular}{|c|c|c|c|c|c|}
\hline Sumber keragaman & $\mathrm{Db}$ & $\mathrm{JK}$ & KT & $F_{\text {hitung }}$ & $\mathrm{F}_{\text {tabel 5\% }}$ \\
\hline Perlakuan & 4 & 193.070 & $48.267,5$ & \multirow{3}{*}{$1,321^{\mathrm{tn}}$} & \multirow{3}{*}{3,06} \\
\hline Galat & 15 & 547.825 & $36.521,66$ & & \\
\hline Total & 19 & 740.895 & $84.789,16$ & & \\
\hline
\end{tabular}

Keterangan: ${ }^{\text {tn }}$ Berpengaruh Tidak Nyata

Hasil uji statistik menggunakan Analisis Varians pada pola Rancangan Acak Lengkap diperoleh hasilnya $F_{\text {hitung }}(1,321)<F_{\text {tabel }}(3,06)$, atau dapat dikatakan bahwa pemberian pakan limbah bayam perpengaruh tidak nyata terhadap pertambahan bobot badan ayam kampung periode grower sehingga tidak dilanjutkan dengan uji Beda Nyata Terkecil (BTN).

\section{Konversi Pakan}

Untuk mengetahui seberapa besar pakan yang dihabiskan oleh ayam kampung periode grower dibandingkan dengan pertambahan bobot badan maka dilakukan perhitungan uji beda rata-ratanya dalam bentuk konversi pakan.

Berdasarkan hasil analisis, tampak bahwa rata-rata konversi pakan untuk setiap perlakuan adalah $\mathrm{P}_{0}$ (kontrol) sebesar 1,37 gram, $\mathrm{P}_{1}(5 \%)$ sebesar 1,61 gram, $\mathrm{P}_{2}(10 \%)$ sebesar 1,59 gram, $\mathrm{P}_{3}(15 \%)$ sebesar 2,99 dan $\mathrm{P}_{4}(20 \%)$ sebesar 2,44 garam. Selengkapnya berikut ditampilkan diagram pengaruh pemberian limbah bayam terhadap koversi pakan ayam kampung periode grower Gambar 3. 


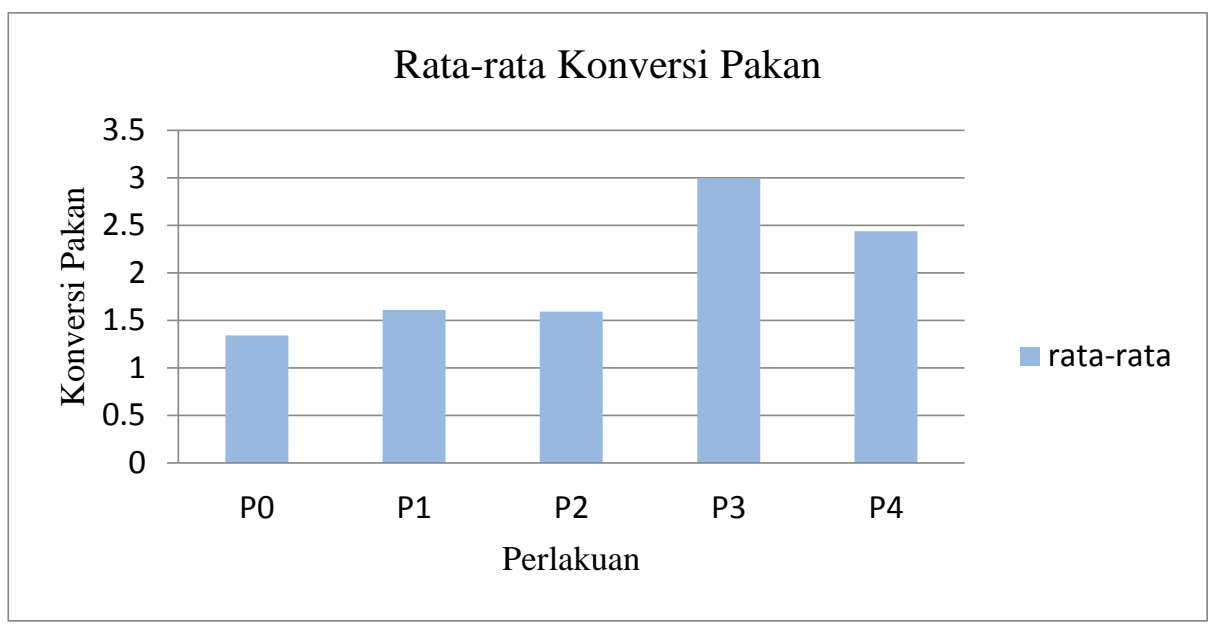

Gambar 3. Diagram Konversi Pakan Ayam Kampung Periode Grower

Hasil analisis ragam selanjutnya dianalisis secara statistik menggunakan ANAVA (analisis varians) dengan pola RAL pada Tabel 5 berikut:

Tabel 5. Analisis Sidik Ragam Perlakuan Pemberian Bayam

\begin{tabular}{|l|l|l|l|l|l|}
\hline Sumber keragaman & Db & JK & KT & F hitung & $F_{\text {tabel 5\% }}$ \\
\cline { 1 - 4 } Perlakuan & 4 & 8,98 & 2,24 & & \\
\cline { 1 - 5 } Galat & 15 & 25,85 & 1,72 & \multirow{2}{*}{$1,302^{\text {tn }}$} & 3,06 \\
\hline Total & 19 & 34,83 & 3,96 & & \\
\hline
\end{tabular}

Keterangan: ${ }^{\text {tn }}$ Berpengaruh Tidak Nyata

Berdasarkan hasil uji statistik menggunakan ANAVA dengan pola RAL diperoleh $F_{\text {hitung }}(1,302)<F_{\text {tabel }}(3,06)$. Dengan demikian dapat dinyatakan bahwa pemberian pakan limbah sayur bayam tidak perpengaruh nyata terhadap konversi pakan ayam kampung periode grower, sehingga tidak perlu dilanjutkan dengan uji BTN untuk mengetahui beda nyata pada taraf terkecil.

\section{Pengaruh Perlakuan Terhadap Konsumsi Pakan Ayam Kampung}

Gambar 1 terlihat bahwa peningkatan konsumsi pakan ayam kampung periode grower terjadi pada perlakuan $\mathrm{P}_{2}(10 \%)$, hal ini disebabkan karena ransum dengan tambahan limbah bayam terdapat keseimbangan nutrisi yang dibutuhkan oleh ayam kampung sehingga serat yang dibutuhkan dari tambahan pakan seperti limbah bayam pada jumlah yang terbatas. Sedangkan kelompok $\mathrm{P}_{3}(15 \%)$ mempunyai rata-rata konsumsi pakan yang paling rendah, hal ini disebabkan karena hijauan (dalam hal ini limbah bayam) mengandung serat kasar yang tinggi, sedangkan ayam mempunyai keterbatasan dalam mencerna serat kasar, sehingga hasil pencernaan yang diserap tubuh menjadi terbatas pula . hal ini yang menyebabkan ayam kampung pada perlakuan $\mathrm{P}_{3}$ indeks konsumsi yang terendah (Fitriani, Tanpa tahun). Sedangkan untuk perlakuan $\mathrm{P}_{0}$, $\mathrm{P}_{1}$ dan $\mathrm{P}_{4}$ mengalami peningkatan konsumsi pakan walaupun tidak berbeda nyata. Hal ini disebabkan oleh berbagai faktor diantaranya faktor eksternal yakni organoleptik dari pakan dan temperatur lingkungan. Sedangkan faktor internalnya adalah spesies, umur, 
dan berat badan. Wahju menyatakan bahwa jumlah pakan yang dikonsumsi ayam kampung periode grower tergantung pada bentuk, bau dan rasa ransum, spesies, umur, berat badan, temperatur lingkungan dan tingkat kecernaan pakan (Ruly D. A, Tanpa Tahun).

Rasyaf (1991), menyatakan bahwa ransum yang berkualitas baik dan ekonomis belum tentu akan membuahkan imbalan yang baik bila konsumsi pakan itu sendiri tidak baik. Konsumsi pakan tidak berdiri tunggal, dalam arti tidak hanya sekedar ayam lapar lalu makan. Tetapi ada beberapa hal yang mempengarui konsumsi pakan, yaitu: Kesehatan ayam. Ayam yang sedang sakit tentu akan terganggu selera makannya. Misalnya ayam yang terserang telo dan pilek ayam, hanya mendekam. Bila hal ini terjadi konsumsi ransum berkurang. Keadaan cuaca panas menyebabkan ayam tidak gairah makan terlalu banyak. Ayam kampung memang adaptif terhadap cuaca tropis, tetapi bila sudah lebih dari $33^{\circ} \mathrm{C}$ ayam sudah gemar minum dari pada makan. Dalam kondisi ini konsumsi ransum berkurang oleh sebab dari luar.

Konsumsi ransum juga di pengaruhi oleh ransum itu sendiri seperti ransum yang mengandung bahan makanan yang tidak disukai oleh ayam kampung. Bila hal ini terjadi, ayam akan hanya mengais-ngais dan makan karena terpaksa, tidak ada pilihan lain. Selama hal ini terjadi, sudah tentu konsumsi untuk menjamin kecukupan jumlah nutrisi tidak akan terpenuhi. Ransum telah rusak, ransum yang berbau tengik tidak akan disentuh oleh ayam dan hal ini jelas akan menyebabkan konsumsi ransum terpengaruh. Pertumbuhan seekor ternak berhubungan erat dengan jumlah ransum yang dikonsumsinya, oleh karena itu perlu diketahui banyaknya ransum yang dikonsumsi oleh ayam tersebut.

\section{Pengaruh Perlakuan Terhadap Pertambahan Bobot Badan Ayam Kampung}

Rata-rata pertambahan bobot badan ayam kampung periode grower tertinggi dicapai pada perlakuan $\mathrm{P}_{0}$ (tanpa penambahan limbah bayam), $\mathrm{P}_{1}(5 \%)$ dan $\mathrm{P}_{2}(10)$, sedangkan bobot badan terendah di capai oleh kelompok $\mathrm{P}_{3}(15 \%)$ dan $\mathrm{P}_{4}(20 \%)$. Sehingga dapat diketahui bahwa semakin tinggi persentase penambahan bayam dalam ransum maka pertambahan bobot badan ayam kampung periode grower semakin rendah jika dibandingkan dengan kontrol. Rata-rata pertambahan bobot badan ayam kampung periode grower pada setiap perlakuan pada minggu pertama sampai minggu ke empat mengalami peningkatan. Ini diduga bahwa kebutuhan akan konsumsi setiap minggunya semakin meningkat sejalan dengan pertambahan bobot badannya. Semakin tinggi pertambahan bobot badan ayam kampung periode grower berbanding lurus dengan pertambahan akan kebutuhan pakan. Perlakuan $\mathrm{P}_{0}$ memiliki rata-rata pertambahan bobot badan yang paling tinggi, diikuti dengan $\mathrm{P}_{1}$ dan $\mathrm{P}_{2}$. Sedangkan untuk kelompok perlakuan $\mathrm{P}_{3}$ dan $\mathrm{P}_{4}$ rata-rata pertambahan bobot badannya rendah. Pertambahan bobot badan ayam kampung periode grower yang lamban ini disebabkan karna campuran bayam semakin banyak pada kelompok $\mathrm{P}_{3}$ ( $15 \%$ bayam) dan $\mathrm{P}_{4}$ (20\% bayam), berdampak pada rendahnya 
selera makan ayam kampung periode grower karena semakin banyak pakan yang berbentuk butiran dan bertekstur keras untuk ransum campuran dedak dengan limbah bayam semakin tidak disukai ayam kampung dan pengaruh terhadap daya konsumsinya. Selama penelitian tampak bahwa pakan yang berbentuk mash (tepung) lebih disukai ayam kampung periode grower dari pada bentuk butiran bertekstur keras. Hal ini karena ayam yang digunakan dalam penelitian ini adalah periode grower yang pakannya masih didominasi oleh yang bersifat tepung sesuai dengan usia dan perkembangan alat pencernaanya.

Pachman menyatakan bahwa untuk memperoleh kenaikan berat badan ayam kampung yang tinggi dibutuhkan konsumsi pakan yang tinggi pula. Konsumsi pakan yang rendah menyebabkan kebutuhan energi untuk proses metaboisme dan pertumbuhan jaringan tidak terpenuhi sehingga mengkibatkan rendahnya pertambahan bobot badan. Konsumsi pakan semakin menurun dengan meningkatnya level campuran bayam, sehingga mengakibatkan konsumsi energi semakin menurun dan mengakibatkan rendahnya pertambahan bobot badan.

Tidak semua makanan yang dimakan ayam digunakan untuk pembentukan daging dan pertambahan bobot badan. Di antaranya digunakan untuk proses fisiologi tubuh, seperti gerakan tubuh, aliran darah, pembentukan bulu dan lain-lain. Inilah yang dinamakan kebutuhan pokok untuk hidup yang harus dipenuhi ayam untuk survive. Ada bagian makanan yang tidak sempat dicerna atau memang tidak mampu dicerna ayam akan terbuang sebagai tinja. Bila ini terjadi maka tampaklah bahwa pakan yang diberikan buruk dan berdampak negatif terhadap konversi pakan. Bagian akhir dari proses pencernaan pakan barulah dipergunakan untuk produksi daging. Jelas bahwa produksi daging baru akan terbentuk bila kebutuhan untuk hidup pokok sudah terpenuhi. Rasyaf (2006), menyatakan bahwa bobot badan dipengaruhi oleh kualitas dan kuantitas pakan yang dikonsumsi, dengan demikian perbedaan kandungan zat-zat makanan pada pakan dan banyaknya pakan yang dikonsumsi akan memberikan pengaruh terhadap pertambahan bobot badan yang dihasilkan, karena kandungan zat-zat makanan yag seimbang dan cukup sesuai dengan kebutuhan pertumbuhan yang optimal.

\section{Pengaruh Perlakaun Terhadap Konversi Pakan Ayam Kampung}

Berdasarkan gambar 3 terlihat bahwa konversi pakan mengalami peningkatan, yaitu dari perlakuan $\mathrm{P}_{0}, \mathrm{P}_{1}, \mathrm{P}_{2}, \mathrm{P}_{3}$ dan $\mathrm{P}_{4}$ pada penggunaan $0 \%, 5 \%, 10 \%, 15 \%$, dan $20 \%$ campuran limbah bayam. Pada perlakuan $\mathrm{P}_{3}(15 \%)$ sebesar 2,99 dan $\mathrm{P}_{4}(20 \%)$ sebesar 2,44 memiliki angka konversi pakan yang tinggi disebabkan oleh besarnya pakan yang dikonsumsi dan tidak diimbangi dengan pertambahan bobot badan. Sedangkan pada $\mathrm{P}_{0}$ (control), $\mathrm{P}_{1}(5 \%)$ dan $\mathrm{P}_{2}(10 \%)$ yang menghasilkan angka konversi pakan rendah dikarenakan pakan yang dikonsumsi dapat dimaksimalkan untuk proses pertumbuhan sehingga berpengaruh terhadap pertambahan bobot badan ayam kampung. Sejauh ini limbah bayam belum dimanfaatkan secara maksimal, sehingga pemanfaatannya sebagai 
bahan pakan ayam 5\% dan 10\% dapat mengurangi biaya pakan ayam kampung. Julferina menyatakan bahwa dalam konversi pakan, sebaiknya dipilih angka konversi terendah. Semakin kecil nilai konversi pakan semakin baik mutu ransum. Jika angka konversi pakan cukup tinggi hal ini disebabkan karena konsumsi pakan tidak seimbang dengan pertambahan bobot badan yang dihasilkan (Sri Julferina, 2008). Tinggi rendahnya angka konversi pakan disebabkan adanya selisih yang semakin besar atau rendah pada perbandingan konsumsi pakan dan pertambahan bobot badan. Hal tersebut didukung oleh Mulyono angka konversi pakan yang tinggi menunjukkan penggunaan pakan yang kurang efisien. Amrullah menyatakan bahwa konversi pakan yang baik berkisar antara 1,75-2,00. Semakin rendah angka konversi pakan berarti kualitas pakan semakin baik. Nilai konversi pakan yang tinggi menunjukkan jumlah pakan yang dibutuhkan untuk menaikkan bobot badan semakin meningkat dan efisien pakan semakin rendah. Dari angka konversi pakan dapat diketahui pakan mana yang lebih efesien digunakan. Angka konversi pakan menunjukan tingkat efesiensi penggunaan ransum, yaitu angka konversi semakin besar maka penggunaan ransum kurang ekonimis.

\section{KESIMPULAN}

1. Ada pengaruh yang tidak nyata pada pola ransum dengan penambahan limbah bayam terhadap konsumsi pakan ayam kampung periode grower.

2. Ada pengaruh yang tidak nyata pada pola ransum dengan penambahan limbah bayam terhadap pertambahan bobot badan ayam kampung periode grower.

3. Ada pengaruh yang tidak nyata pada pola ransum dengan penambahan limbah bayam terhadap konversi pakan ayam kampung periode grower.

4. Penggunaan limbah bayam sebanyak $10 \%$ dalam ransum ayam kampung periode grower dapat meningkatkan konsumsi pakan, dan merupakan konsumsi pakan tertinggi yang dicapai.

5. Peningkatan pertambahan bobot badan ayam kampung periode grower terjadi pada tanpa campuran limbah bayam.

6. Penurunan angka konversi pakan ayam kampung periode grower terjadi pada tanpa campuran limbah bayam.

\section{SARAN}

Saran yang dapat diajukan dari hasil penelitian ini adalah: limbah bayam dapat dipergunakan sebagai campuran ransum pakan ayam kampung periode grower dengan komposisi sebesar 10\% sekaligus merupakan langkah penghematan biaya produksi. 


\section{DAFTAR PUSTAKA}

Amrullah, I. K. 2004. Nutrisi Ayam Petelur. Cetakan Ke-3. Bogor: Lembaga Satu Gunung Budi

Ariska Dwi Rully.2008. Pengaruh Pemberian Campuran Onggok Dan Molase Terfermentasi Terhadap Konsumsi Pakan, Konversi Pakan Dan Pertambahan Bobot Badan Ayam Pedaging. Jurnal. UIN Maliki Malang.

Bandini. Y. 2003. Mengenal Tanaman Bayam. Jurnal Agrobisnis Pertanian Vol 5 No 2.

Doraja. P. H. 2012. Biodegradasi Limbah Domestik Dengan Menggunakan Inoculum Alami Dari Tangki Septik. Jurnal Sains Dan Seni ITS Vol 1 No 1.

Hartanto. 2008. Pengeruh Penggantian Konsentrasi Dengan Daun Lamtoro Kering (Leucaena leucocepala) Dalam Ransum Terhadap Performa Kambing Kacang Jantan. Skripsi Program Strata Satu (S1) Universitas Sebelas Maret.

Julferina Sri. 2008. Pemanfaatan Tepung Keong Mas sebagai Substitusi Tepung Ikan Dalam Ransum Terhadap Performans Kelinci Jantan Lepas Sapih. Skripsi Program Strata Satu (S1) Universitas Sumatera Medan.

Masanto Ryan. 2008. Meraih Untung Dengan Ayam Kampung. Yogyakarta: PT Citra Aji Parama.

Masrurah Luluk. 2008. Pengaruh Penggunaan Limbah Padat Tahu Dalam Ransum Terhadap Konsumsi Pakan, Pertambahan Bobot Badan Dan Konversi Pakan Pada Ayam Kampung (Gallus domesticus) Periode Grower. Skripsi Program Strata Satu (S1) Universitas Islam Negeri Malang.

Mihrani. 2006. Pengaruh Campuran Ransum Komersial Dan Dedak Padi Yang Di

Tambah $\mathrm{Caco}_{3}$ Dan Premix A Terhadap Pertumbuhan Ayam Buras Periode Starter. Jurnal Agrisistem Vol 2 No 1.

Mulyono. A. M. W. 2009. Nilai Nutritive Onggok-Terfermentasi Mutan Trichorderma

AAI Pada Ayam Broiler. Yogyakarta: Media Kedokteran Hewan Fakultas Pertanian, Universitas Veteran Bangun Nusantara

Rahayu Imam. 2003. Ayam Merawang Ayam Kampung Pedaging dan Petelur. Jakarta: Penebar Swadaya.

Rasyaf. M. 2006. Manajemen Peternakan Ayam. Jakarta: Penebar Swadaya.

Rasyaf, M. 1991. Seputar Makanan Ayam Kampung. Bogor: Kanisius.

Rasyaf, M. 1995. Pengelolaan Usaha Peternakan Ayam Pedaging. Jakarta: PT Gramedia Pustaka Utama.

Sarwono B. 1990. Beternak Ayam Buras. Jakarta: Pondok Gede

Sufi Ichsan. 2006. Limbah Pasar Alternatif Penyedia Hijauan. Jurnal Ilmu-Ilmu Ternak Vol. 15 No. 2.

Sukanto. 1997. Mari Beternak Ayam. Semarang: CV Aneka Ilmu.

Suneth Bakry. 2003. Informasi Teknologi Peternakan Bagian Proyek Pembibitan Ternak Maluku. Ambon. 
US Fitriani.2007. Pengaruh Pola Ransum Dengan Penambahan Limbah Udang Dan Bayam Terhadap Peningkatan Bobot Badan Ayam Kampung. Skripsi IKIP PGRI Semarang.

Yuwanta Tri. 2004. Dasar-Dasar Ternak Unggas. Yogyakarta: Kanisius. 